\title{
Feeding Diets Containing Different Forms of Duckweed on Productive Performance and Egg Quality of Ducks
}

\author{
B. Indarsih* \& M. H. Tamsil \\ Faculty of Animal Science, University of Mataram \\ Jln. Majapahit No. 62 Mataram-Lombok NTB, Indonesia \\ (Received 17-01-2012; accepted 14-08-2012)
}

\begin{abstract}
ABSTRAK
Penelitian ini dilakukan untuk mempelajari pengaruh pemberian pakan mengandung duckweed dengan penyajian berbeda pada itik lokal terhadap performan produksi dan kualitas kuning telur. Sebanyak 90 ekor itik berumur 24 minggu secara acak dibagi menjadi 18 kelompok dan ditempatkan masing-masing pada unit kandang berukuran $2 \times 1 \mathrm{~m}^{2}$. Penelitian menggunakan rancangan acak lengkap dengan tiga perlakuan yang masing-masing terdiri atas 6 ulangan. Perlakuan P1 adalah kelompok itik yang diberi pakan komplit mengandung duckweed $20 \%$ dan disajikan dalam bentuk mash kering, P2 adalah kelompok itik yang diberi pakan komplit mengandung duckweed $20 \%$ dan disajikan dalam bentuk basah (bubur) dan P3 diberi ransum basal disajikan dalam bentuk mash kering dan duckweed disajikan secara terpisah dalam bentuk segar. Ransum disusun dengan kandungan nutrisi sama. Konsumsi, konversi pakan, dan pigmentasi kuning telur dipengaruhi oleh cara penyajian duckweed. Pemberian duckweed segar mempunyai potensi yang baik untuk diterapkan dalam mengurangi biaya pengolahan pakan.
\end{abstract}

Kata kunci: itik lokal, duckweed, produksi telur, pigmentasi kuning telur

\section{ABSTRACT}

The present experiment was undertaken to study the feeding effect of diets containing different forms of duckweed for local ducks on their productive performance and egg quality or egg yolk pigmentation. A total of 90 birds of 24 wk old ducks were randomly divided into 18 experimental units of $2.0 \times 1.0 \mathrm{~m}^{2}$ of cages. The experiment was assigned in a completely randomized design (3 treatments with 6 replicates, 5 birds each). There were 3 dietary treatments, namely P1= ducks fed a complete diet containing $20 \%$ of dried duckweed and given in the form of dry-mash; $\mathrm{P} 2=$ a complete diet in P1 but it was offered in wet form (slurry); and P3= ducks were offered basal diet in the form of dry-mash and fresh duckweed was offered separately ad libitum. Diets were formulated to have similar nutritional contents. Feed consumption, feed conversion ratio (FCR), and egg yolk pigmentation were measured. The result of the study showed that these three parameters were affected by the feeding different forms of duckweed. Feeding diet with fresh duckweed brought about the best pigmentation than did the dry one. Fresh duckweed offers a promise as a potential feedstuff for ducks and has a good implication in reducing feed processing cost.

Key words: local duck, duckweed, egg production, yolk pigmentation

\section{INTRODUCTION}

Ducks, known as water fowl, a type of poultry that has a considerable contribution in providing animal protein sources. In the year 2007, duck eggs production could supply as much as $14.66 \%$ of national needs (DGLS, 2008). The duck eggs are mostly obtained from

\footnotetext{
* Corresponding author:

E-mail: budiindarsih@gmail.com
}

the traditional rearing in wet rural areas. Improvement of rearing ducks in a confined housing model to be a large scale has been limited by the low selling value of eggs which is not able to offset the cost of production. The unavailability of local feed/feedstuffs at low prices is one reason that brings about the farmers more reliant in feeding their ducks with commercial feed although the production cost get higher.

A possible effort can be alternatively selected to reduce production cost is that by feeding a mixture of rice bran and a commercial feed. However, it has a negative 
impact on egg quality, especially the yellow pigmentation of egg yolk. The low level of $\beta$-carotene in the diet, due to the low content of yellow corn, is the main cause of low egg yolk pigmentation. The use of duckweed, a potential local feedstuff with low price, is one alternative to overcome the problem, because it contains high $\beta$-carotene $(111.24 \mathrm{mg} / \mathrm{kg}$ dry matter) and crude protein $(29.05 \%)$ (Anderson et al., 2011) and it can be cultivated to produce high biomass (Cheng \& Stomp, 2009).

Duckweed that grew in wastewater contains protein of 35 to $45 \%$ on dry matter basis with high availability of essential amino acids (Islam, 2002; Khanum et al., 2005). Duckweed grows well in the water with low N content, (Leng et al., 1995; Islam, 2002; Goopy \& Murray, 2003). It has rapid vegetative reproduction, easily adapt to unfavorable environmental conditions, and it has detoxication ability (Czerpak \& Szamrej, 2003). Lysine content of duckweed as an animal feed also met the standard recommended by FAO and it is generally higher than that found in grain (Cheng \& Stomp, 2009). Feeding duckweed has been studied in broiler chickens (Syamsuhaidi, 1997; Kabir et al., 2005), native chickens (Khang \& Ogle, 2004; Thuy \& Ogle, 2007), laying hens (Anderson et al., 2011), breeding ducks (Men et al., 2001a), growing ducks (Men et al., 2001b), and in laying ducks (Tamsil \& Indarsih, 2003; Khandaker et al., 2007).

Feeding duckweed in laying hens up to $40 \%$ in the diet did not interrupt egg production and considerably increased egg yolk pigmentation (Islam, 2002). In growing crossbred ducks, fresh duckweed could completely replace roasted soya beans and a vitamin-mineral premix in broken rice based diets without reduction in growth performance (Men et al., 2001b). In broiler chickens, inclusion of duckweed up to $15 \%$ in diet did not reduce growth rate (Syamsuhaidi, 1997; Ahammad et al., 2003). According to Thuy \& Ogle (2007), when native chickens were offered a selection to paddy rice, fish meal and duckweed in confined and scavenging treatments up to $20 \mathrm{wk}$ of age, duckweed intakes (g Dry Matter= DM/ day) was higher in confined than scavenging chickens (8.40 and 4.84). However, fish meal intakes (g DM/day) were almost similar in both systems of rearing (7.95 and 7.64). Hen-day production was 3.4\% significantly higher in confinement than scavenging $(25.4 \%$ and $22.0 \%)$, with egg weight and egg yolk color were similar. It means that duckweed was more preferable and also able to be a supplementary crude protein source in confinement rearing. The inclusion of $20 \%$ duckweed into the rations of laying ducks did not hamper egg production, but increased feed conversion due to a large amount of feed scattered on the drinking water bucket (between 10\% to $15 \%$ ). Therefore, duckweed was suggested to be provided in fresh or dry pelleted form (Tamsil \& Indarsih, 2003). Duckweed could replace up to $6 \%$ of sesame oil cake in broilers diet offered until $42 \mathrm{~d}$ of age (Ahammad et al., 2003). Ducks which consumed fresh duckweed grew well (Burkmar, 2003; Forbes, 2003). However, the information concerning feeding fresh duckweed in relation to productive performance and egg yolk pigmentation is not available. Therefore, this study was carried out to confirm the potential of fresh duckweed as a feed ingredient and as a source of pigments for ducks.

\section{MATERIALS AND METHODS}

\section{Birds and Management Procedure}

The total of 24 wk old local ducks (average body weight was $1401 \pm 29 \mathrm{~g}$ ) were used to study the response in terms of productive performance and egg yolk pigmentation due to the feeding effect of diets containing different forms of duckweed. A total of 90 ducks were randomly divided into 18 goups reared in bamboo cages of $2.0 \times 1.0 \mathrm{~m}$ in size with 5 birds each. Each cage was equipped with one round plastic bucket $25 \mathrm{~cm}$ in diameter and $20 \mathrm{~cm}$ in deep for drinking water and one circular feeder except that for the groups fed fresh duckweed, another type of feeder was used. Body weight of birds and feed were weighed weekly.

\section{Dietary Treatments and Feeding Programs}

Three dietary treatments (Table 1) composed of different forms of duckweed and formulated to have similar nutritional contents (calculated values). Dietary treatment of P1 was the basal diet containing 20\% of duckweed and was provided in the form of dry mash representing a control diet used in the previous study (Tamsil \& Indarsih, 2003). Dietary treatment of P2 was similar to that of $\mathrm{P} 1$, but the diet was offered in a wet form (slurry). Dietary treatment of P3 was the diet with similar composition as that of P1, but duckweed was offered separately ad libitum in fresh form three times per day to minimize spillage. The scattered feed in drinking

Table 1. Composition and nutritional content of experimental diets

\begin{tabular}{lrcc}
\hline \multirow{2}{*}{ Ingredients (\%) } & \multicolumn{3}{c}{ Dietary treatments } \\
\cline { 2 - 4 } & $\mathrm{P} 1$ & $\mathrm{P} 2$ & $\mathrm{P} 3$ \\
\hline Yellow corn & 41.0 & 41.0 & 41.0 \\
Soybeans & 5.0 & 5.0 & 5.0 \\
Rice bran & 26.0 & 26.0 & 26.0 \\
Local fish meal & 4.0 & 4.0 & 4.0 \\
CaCO $_{3}$ & 3.0 & 3.0 & 3.0 \\
Premix & 1.0 & 1.0 & 1.0 \\
Duckweed & 20.0 & 20.0 & offered fresh \\
Total & 100.0 & 100.0 & ad libitum \\
Calculated nutrient & & & \\
Crude protein (\%) & 17.43 & 17.43 & 16.71 \\
Metabolizable & 2,806 & 2,806 & 2,879 \\
energy (Kcal/kg) & & & 6.87 \\
Crude fiber (\%) & 6.87 & 6.87 & 1.7 \\
Calcium (\%) & 1.6 & 1.6 & 0.8 \\
Phosphor (\%) & 0.9 & 0.9 & \\
\hline
\end{tabular}

Note: P1=diet with $20 \%$ dried duckweed was given in the form of drymash; P2=diet with $20 \%$ dried duckweed was given in the form of a wet (slurry); P3= diet was given in the form of dry-mash and fresh duckweed was offered separately ad libitum. 
water was filtered, dried and weighed for correction of the actual feed intake.

\section{Data Collection}

Feed intake, feed conversion, egg production, and egg weight were observed. In case of P3, feed intake of the basal diet was weekly calculated, while consumption of fresh duckweed was calculated daily, and it was further converted into dry weight basis and summed with the consumption of basal diet without duckweed to obtain the cumulative feed intake (Table 3). Egg production was recorded daily until $8 \mathrm{wk}$ of laying period. The egg quality data was collected weekly.

\section{Experimental Design and Statistical Analysis}

The present experiment was assigned in a completely randomized design with 3 dietary treatments (P1, P2, and P3) and 6 replications each. Data were subjected to analysis of variance, and significant differences among treatment means were separated using Duncan's multiple range test at 5\% probability (Steel \& Torrie, 1993)

\section{RESULTS AND DISCUSSION}

\section{Productive Performance}

Feed intake of birds offered the diet containing duckweed in wet form (slurry) was -(P2) lower than those offered dry-mash (P1) or dry-mash with fresh duckweed (P3) (P<0.05) (Table 2). Feeding dry-mash form in P1 and P3 might change the eating behavior of the ducks. The eating behavior had an impact on the number of waste feed which was associated with the anatomy of the beak (Adeola, 2006). Tamsil \& Indarsih (2003) suggested that feeding pellets or slurry form was beneficial. Forbes (2003) showed that wet feeding for laying hens can improve egg production from $58.6 \%$ to $76 \%$ and improved feed efficiency from 0.28 to 0.35 . The advantage of feeding wet feed was to reduce the cost of feed processing mainly composed on cereal base ingredients. This study showed that feeding diet containing $20 \%$ duckweed in fresh form (P3) had no effect on feed

Table 2. Actual feed intake, egg production, egg weight, and feed conversion of ducks at $8 \mathrm{wk}$ of production period

\begin{tabular}{lrrr}
\hline \multirow{2}{*}{ Variables } & \multicolumn{3}{c}{ Dietary treatments } \\
\cline { 2 - 4 } & \multicolumn{1}{c}{$\mathrm{P} 1$} & $\mathrm{P} 2$ & $\mathrm{P} 3$ \\
\hline $\begin{array}{l}\text { Feed intake } \\
\text { (g/bird/d) }\end{array}$ & $154.60 \pm 4.00^{\mathrm{a}}$ & $122.60 \pm 4.50^{\mathrm{b}}$ & $156.50 \pm 2.00^{\mathrm{a}}$ \\
Feed conversion & $7.65 \pm 0.51^{\mathrm{a}}$ & $5.31 \pm 0.56^{\mathrm{b}}$ & $7.25 \pm 0.10^{\mathrm{a}}$ \\
Egg production $(\%)$ & $38.70 \pm 4.50$ & $39.70 \pm 7.50$ & $39.40 \pm 7.60$ \\
Egg weight $(\mathrm{g} / \mathrm{egg})$ & $64.60 \pm 3.00$ & $62.20 \pm 1.90$ & $65.40 \pm 1.10$ \\
\hline
\end{tabular}

Note: P1=diet with $20 \%$ dried duckweed was given in the form of drymash; P2=diet with $20 \%$ dried duckweed was given in the form of a wet (slurry); P3= diet was given in the form of dry-mash and fresh duckweed was offered separately ad libitum. Means in the same row with different superscript differ significantly $(\mathrm{P}<0.05)$. intake, but the reduction of feed intake was noted when the duckweed was dried and mixed with other component and offered in slurry form (P2).

Feed conversion ratio was significantly $(\mathrm{P}<0,05)$ affected by feeding system with the highest value was found in the group of P1 diet, while the lowest one was indicated by that of P2 diet (Table 2). The high feed conversion of the treatments of P1 and P3 was likely associated with the different in nutrietns digestion characteristics. Addition of water to make slurry diet might improve the rate of passage and the contact between intestinal enzyme and feed particles leading to improvement in nutrients utilization and metabolism. Feed conversion found in the present study was quite high, ranging from 5.31 to 7.65 . The performance of the laying ducks in the present study was lower compared to the finding of Ketaren \& Prasetyo (2002) who reported that feed conversion of crossbred duck between Mojosari and Alabio (MA) at 22 to 42 wk of age was 2.88 and the egg production was almost two fold higher $(83.31 \%)$. In this study the egg weight (62.2 to $65.4 \mathrm{~g}$ ) and feed conversion (5.31 to 7.65 ) were higher than egg weight (51.9 to 54.9 g) and feed conversion values (9.03 to 15.14) at the same age reported by Tamsil \& Indarsih (2003).

Feeding diets containing duckweed did not affect egg production and egg weight $(\mathrm{P}>0.05)$. However, egg production in this study was quite low (38.7\% to $39.7 \%)$, whereas normal egg production when ducks were raised in traditional systems ranged from $26.9 \%$ to $41.3 \%$ (Ketaren, 2007). However, in an intensive rearing system, egg production could reach $55.6 \%$, even Prasetyo \& Susanti (2000) reported that egg production of dry system of raising ducks, regardless of genotype, was able to reach 66.75 eggs $(73 \%)$ in the first 3 mo of laying period. The low egg production in this study was due to the period of data collection was only 2 mo and the egg production would increase in the rest of laying period. The present result was similar to the previous study reported by Tamsil \& Indarsih (2003) that egg production of local Lombok ducks was $26.3 \%$ to $31.3 \%$ in the first 3 mo of egg-laying period.

\section{Egg Quality}

Feeding of diets containing duckweed in different form did not affect egg weight, egg white and yolk weights, and shell thickness (Table 3 ), but it improved the pigmentation of egg yolk $(\mathrm{P}<0.05)$. These were due to the same nutritional value of diet offered (Table 1). Feeding a layer diet containing $12.6 \%$ dried duckweed in laying hens improved yolk color compared (Anderson et al., 2011). However, a significant increased in the pigmentation of egg yolk color was indicated by the ducks given diet containing fresh duckweed. This was possibly due the deposition of $\beta$-carotene and xanthophylls supplied by fresh duckweed. Conversely, the availability of $\beta$-carotene and xanthophylls in the dried duckweed of diets P1 and P2 might be reduced by heat during drying resulting in low yolk pigmentation. Men et al. (2001b) reported that the carotene content of fresh duckweed was $1,025 \mathrm{mg} / \mathrm{kg} \mathrm{DM}$ or in the range of $66-110 \mathrm{mg} / \mathrm{kg}$ (Dudley et al., 1981). This study showed better result 
Table 3. Egg characteristics as responses to feeding systems of diets containing duckweed

\begin{tabular}{lccc}
\hline \multirow{2}{*}{\multicolumn{1}{c}{ Variables }} & \multicolumn{3}{c}{ Dietary treatments } \\
\cline { 2 - 4 } & P1 & P2 & P3 \\
\hline Egg shell weight (\%) & $13.3 \pm 2.0$ & $14.5 \pm 2.8$ & $11.9 \pm 2.5$ \\
Egg white weight (\%) & $50.3 \pm 3.7$ & $49.5 \pm 3.2$ & $50.3 \pm 2.9$ \\
Egg yolk weight (\%) & $34.3 \pm 2.2$ & $33.6 \pm 2.7$ & $33.6 \pm 2.4$ \\
Egg shell thickness (mm) & $39.0 \pm 2.0$ & $44.0 \pm 2.5$ & $46.0 \pm 2.2$ \\
Egg yolk color & $12.5 \pm 1.5^{\mathrm{a}}$ & $12.5 \pm 1.8^{\mathrm{a}}$ & $13.7 \pm 1.4^{\mathrm{b}}$ \\
\hline
\end{tabular}

Note: P1=diet with $20 \%$ dried duckweed was given in the form of drymash; P2=diet with $20 \%$ dried duckweed was given in the form of a wet (slurry); P3= diet was given in the form of dry-mash and fresh duckweed was offered separately ad libitum. Means in the same row with different superscript differ significantly $(\mathrm{P}<0.05)$.

than those observed by Anderson et al. (2011) where inclusion $12.6 \%$ duckweed containing $61.360 \mathrm{mg} / \mathrm{lb}$ carotene resulted lower yolk color. Thus, efficacy of duckweed as a natural pigmentation was affected by the level used in the diet and the dietary inclusion of $20 \%$ dried duckweed offered reasonable yolk pigmentation. High inclusion was due to low yellowness value of duckweed than the synthetic pigments (Santos-Bocanegra et al., 2004). However, duckweed species is a promising sources of pigments (Chantiratikul et al. 2010).

\section{CONCLUSION}

Feeding a diet containing duckweed in wet (slurry) form improved feed conversion ratio. However, feeding ducks allowing to free access of fresh duckweed improved egg yolk color.

\section{ACKNOWLEDGEMENT}

The author thank to the Government of West Nusa Tenggara Province through Regional Capacity Research Project (PPKD) due to valuable financial support for this study. Grateful thanks are also addressed to Kasri, S. Pt, Rishi Kapur, Supardi, and Imran, graduate students of the Faculty of Animal Science, Mataram University for helpful assistance during the study.

\section{REFERENCES}

Adeola, O. 2006. Review of research in duck nutrient utilization. Int. J. Poult. Sci. 5: 201-218.

Ahammad, M. U., M. S. R. Swapon, T. Yeasmin, M. S. Rahman, \& M. S. Ali. 2003. Replacement of sesame oil cake by duckweed (Lemna minor) in broiler diet. Pakistan J.-Biol. Sci. 6: 1450-1453. http://dx.doi.org/10.3923/pjbs.2003.1450.1453

Anderson, K. E., Z. Lowman, A. M. Stomp, \& J. Chang. 2011. Duckweed as a feed ingredient in laying hen diets and its effect on egg production and composition. Int. J. Poult. Sci. 10: 4-7. http://dx.doi.org/10.3923/ijps.2011.4.7

Burkmar, R. 2003. Living with duckweed. www.spacefornature. co.uk/default.asp? ftr=Features/Projects/...xml (15 January 2010).

Chantiratikul, A., P. Chantiratikul, A. Sangdee, U. Maneechote, C. Bunchasak, \& O. Chinrasri. 2010. Perfor- mance and carcass characteristics of Japanese quails fed diets containing Wolffia Meal [Wolffia globosa (L). Wimm.] as a protein replacement for soybean meal. Int. J. Poult. Sci. 9: 562-566. http://dx.doi.org/10.3923/ijps.2010.562.566

Cheng, J. J. \& A. M. Stomp. 2009. Growing duckweed to recover nutrients from wastewaters and for production of fuel ethanol and animal feed. Env. Biotech. 37: 17-26. doi: 10.1002/clen.200800210

Czerpak, R. \& I. K. Szamrej. 2003. The effect of $\beta$-estradiol and corticosteroids on chlorophylls and carotenoids content in Wolffia arrhiza (L.) Wimm. (Lemnaceae) growing in municipal bialystok tap water. Polish J. Env. Studies 12: 677-684. www.pjoes.com/pdf/12.6/677-684.pdf

DGLS (Directorate General of Livestock Services). 2008. Statistical Book of Livestocks. Directorate General of Livestock Services. Ministry of Agriculture, Jakarta.

Dudley, D., Jr. Culley, E. RejmZinkov, J. Kvet , \& J. B. Frye. 1981. Production, chemical quality and use of duckweeds (Lemnaceae) in aquaculture, waste management, and animal feeds. J. World Maricul. Soc. 12: 27-49.

Forbes, J. M. 2003. Wet foods for poultry. Avian Poult. Biol. Rev. 14: 175 - 193. http://dx.doi.org/10.3184/147020603783 637481

Goopy, J. P. \& P. J. Murray. 2003. A review on the role of duckweed in nutrient reclamation and as a source of animal feed. Asian-Austr. J. Anim. Sci. 16: 297- 305.

Islam, K. M. S. 2002. Feasibility of duckweed as poultry feed: A review. Indian J. Anim. Sci. 72: 486-491. cat.inist.fr/ ?aModele=afficheN\&cpsidt=13791716 (2 Pebruari 2010)

Kabir, J., M. A. Islam, M. U. Ahammad, \& M. A. R. Howlider. 2005. Use of duckweed (Lemna minor) in the diet of broiler. Indian J. Anim. Res. 39: 31-35.

Ketaren, P. P. \& L. H. Prasetyo. 2002. Pengaruh pemberian pakan terbatas terhadap produktivitas itik silang Mojosari x Alabio (MA): 1. Masa bertelur fase pertama umur 20-43 minggu. J. Ilmu Ternak Vet. 7: 38-45.

Ketaren, P. P. 2007. Peran itik sebagai penghasil telur dan daging nasional. Wartazoa 17: 117-127.

Khandaker, T., Md. J. Khan, Md. Shahjalal, \& Md. M. Rahman. 2007. Use of duckweed (Lemna perpusilla) as a protein source feed item in the diet of semi-scavenging jinding layer ducks. Poult. Sci. 44: 314-321. http://dx.doi.org/10.2141/ jpsa.44.314

Khang, N. T. K. \& B. Ogle. 2004. Effects of dietary protein level and a duckweed supplement on the growth rate of local breed chicks. Livestock Research for Rural Development 16 (8). http://www.lrrd.org/lrrd16/8/khan16054.htm (10 January 2012)

Khanum, J., A. Chwalibog, \& K. S. Huque. 2005. Study on digestibility and feeding systems of duckweed in growing ducks. Livestock Research for Rural Development 17 (5). http://www.lrrd.org/lrrd17/5/khan17050.htm (15 November 2011)

Leng, R. A., J. H. Stambolie, \& R. Bell. 1995. Duckweed - a potential high-protein feed resource for domestic animals and fish. Livestock Research for Rural Development 7 (1). http://www.lrrd.org/lrrd17/1/3.htm (14 January 2012)

Men, B. X., B. Ogle, \& J. E. Lindberg. 2001a. Use of duckweed as a protein supplement for breeding ducks. Asian-Aust. J. Anim. Sci. 2002. 15: 866-871

Men, B. X., B. Ogle, \& J. E. Lindberg. 2001b. Use of duckweed as a protein supplement for growing ducks. Asia-Aust.J. Anim.Sci. 14: 1741-1746.

Prasetyo, L. H. \& T. Susanti. 2000. Persilangan timbal balik antara itik Alabio dan Mojosari: periode awal bertelur. J. Ilmu Ternak Vet. 5: 210-213

Santos-Bocanegra, E., X. Ospina-Osorio, \& E. O. OviedoRondón. 2004. Evaluation of xanthophylls extracted from tagetes erectus (marigold flower) and capsicum sp. (red pep- 
per paprika) as a pigment for egg-yolks compare with synthetic pigments. Int. J. Poult. Sci. 3: 685-689. http://dx.doi. org/10.3923/ijps.2004.685.689

Steel, R. G. D. \& J. H. Torrie. 1993. Prinsip dan Prosedur Statistika. Suatu Pendekatan Biometrik. (Alih bahasa: Bambang Sumantri). Penerbit PT. Gramedia, Jakarta.

Syamsuhaidi. 1997. Penggunaan duckweed (Family Lemnaceae) sebagai pakan serat sumber protein dalam ransum ayam pedaging. Disertasi Doktor. Program Pascasarjana Institut Pertanian Bogor.
Tamsil, M. H. \& B. Indarsih. 2003. Meningkatkan produksi telur dan pigmentasi kuning telur itik Lokal Lombok yang dipelihara secara terkurung dengan menggunakan duckweed dalam ransum. J. Ilmu Teknol. Peternakan. 2: 218 - 225.

Thuy, N. T. \& B. Ogle. 2007. Effect of supplementation on growth and laying performance of confined and scavenging local chickens. Livestock Research for Rural Development 19 (2). http://www.lrrd.org/lrrd19/2/thuy 19030.htm (4 April 2011) 